\title{
松代群発地震地域に湧出する深層地下水
}

\author{
信州大学大学院工学系研究科* 奥 澤 保 \\ 信州大学理学部** 塚 原 弘 昭
}

\section{Origin of Deep Ground Water in the Matsushiro Earthquake Swarm Area}

\author{
Tamotsu OKusAwa
}

Graduate School of Science and Technology, Shinshu University, 3-1-1 Asahi, Matsumoto 390-8621, Japan

\author{
Hiroaki TSUKaHARA
}

Fuculty of Science, Shinshu University, 3-1-1 Asahi, Matsumoto 390-8621, Japan

(Received March 27, 2000; Accepted January 15, 2001)

\begin{abstract}
Many small earthquakes occurred in the Matsushiro area in a period from 1965 to 1967 . This is called "Matsushiro Earthquake Swarm". The swarm earthquakes are interpreted as a result of deep ground water intrusion into the focal area. At the hardest time of the crustal movement, water flow from pre-existing springs increased, and many new springs appeared along a hidden fault zone formed by the swarm earthquakes. Some of springs are still alive and have peculiar chemical compositions. The deep ground water must have caused the earthquake swarm. We show the characteristics of the deep ground water through analyzing chemical composition. Our measured data and many published data show that the deep ground water obtains $\mathrm{Ca}^{2+}$ from rocks and loses $\mathrm{Na}^{+}$during its upwelling migration through the fault zone of Matsushiro Swarm Earthquakes. The data also show that the major components of $\mathrm{Cl}^{-}$and $\left(\mathrm{Na}^{+}+\mathrm{Ca}^{2+}\right)$ have a liner relation in concentrations, although every spring water has different concentrations of $\mathrm{Cl}^{-}$and $\left(\mathrm{Na}^{+}+\mathrm{Ca}^{2+}\right)$. It is interpreted in terms of mixing deep ground water with shallow ground water at defferent ratios. The concentrations of the major ions of the deep ground water are estimated from both of our measured data and compiled data using the liner relation, e.g., $\mathrm{Na}^{+}: 310 \mathrm{meq} / l, \mathrm{Cl}^{-}: 330 \mathrm{meq} / l$. Analysis of our measured data also reveals that the small temporal variation in the concentration of $\mathrm{Ca}^{2+}$ in a short period such as several months is attributable to the reaction between the ground water with $\mathrm{CO}_{2}$ and surrounding rocks.
\end{abstract}

Key words: Matsushiro Earthquake Swarm, Deep ground water, Ground water chemistry, Earthquake chemistry, Water induced seismicity.

\section{§1.はじめに}

1965 年に始まった松代群発地震は, 松代地震断層沿 いに上昇してきた深層地下水が引き金になったといわれ る [例えば, 中村 (1971)]. 通常の地表付近の循環水之は 全く異なるイオン組成・濃度をもつこの地下水は, 地震 の原因となるとともに松代地域の湧水・温泉の水質や湧 出量に大きな変化をむたらし, 地盤隆起・沈降, 地滑り などの地表変動の原因ともなった，この深層地下水は, それが地表に現れたときの主要イオン組成から塩化カル シウム型地下水であるといわれていたが，その起源，涌
出機構，地震などの地殼活動との関係について未だ十分 な説明がなされていない.

本研究では, 松代群発地震を引き起こした深層地下水 の初源的な主要イオン組成を明らかにし，松代地震がど のような水によって引き起こされたのか, 初源的地下水 が, どのように変成されて現在の多種多様なイオン組成 をむつ涌水になっているのかについて検討してゆく.

\section{§ 2. 松代群発地震と河水}

松代群発地震はその性状（地震の回数および大きさ・ 
震源の深さ・震源域の拡がり・随伴した地殼変動など） から以下の五つの活動期に分けることができる [HAGIWARA and IWATA (1968)].

第 1 活動期 1965 年 8 月〜 1966 年 2 月（7ヶ月間） 第 2 活動期 1966 年 3 月 1966 年 7 月（5 ヶ月間） 第 3 活動期 1966 年 8 月〜 1966 年 12 月（5 ヶ月 間)

第 4 活動期 1967 年 1 月 1967 年 5 月（5 ヶ月間） 第 5 活動期 1967 年 6 月～現在

松代地震では, 著しい地盤の隆起・伸縮（地殼变動） が生じたが, それが最も活発だったのは第 3 活動期で, この間, 松代盆地内には多数の地割れが生じ, 約 $1 \mathrm{~m}$ に 及ふ震央付近の隆起域から面的な地下水噴出が起こった （4ヶ月間で計約 1 千万 t) [中村 (1971)].この噴出の 後, 隆起域は沈降し始めたが, それに伴い湧水域内で大 小の地滑りが発生した [MORIMOTO et al. (1967)].

こうした地滑りを引き起こした湧水をはじめ，松代盆
地内には大小多々の湧水が新たに出現した，また，既存 の湧水・温泉も，その湧出量や水質に著しい異常を生じ たものが多い。これら湧水は, 群発地震の震源域, すな わち皆神山から松代地震断層の直上およびその周辺に多 くみられ，行政区分としては長野市松代町東寺尾・加賀 井地区から東条・牧内地区に多くみられた (Fig，1)，以 下, この地域を松代群発地震地域と呼ぶことにする.

松代群発地震を特徵づけるこれら湧水に関しては, 群 発地震が始まった前後より様々な研究がなされており, 地震と地下水との関連について多くの仮説が提出され た. 湧水の出現および変化が, 地震活動の原因であるの かあるいは結果であるのか, 大量の地下水がいったいど こから来たのかについて，系統的に説明された定説と呼 べるものはない状態であるが, 松代群発地震と水との関 係について現在までにいわれているところをまとめると 以下のようである.

（1）松代群発地震地域の地表に大量に湧出した湧水

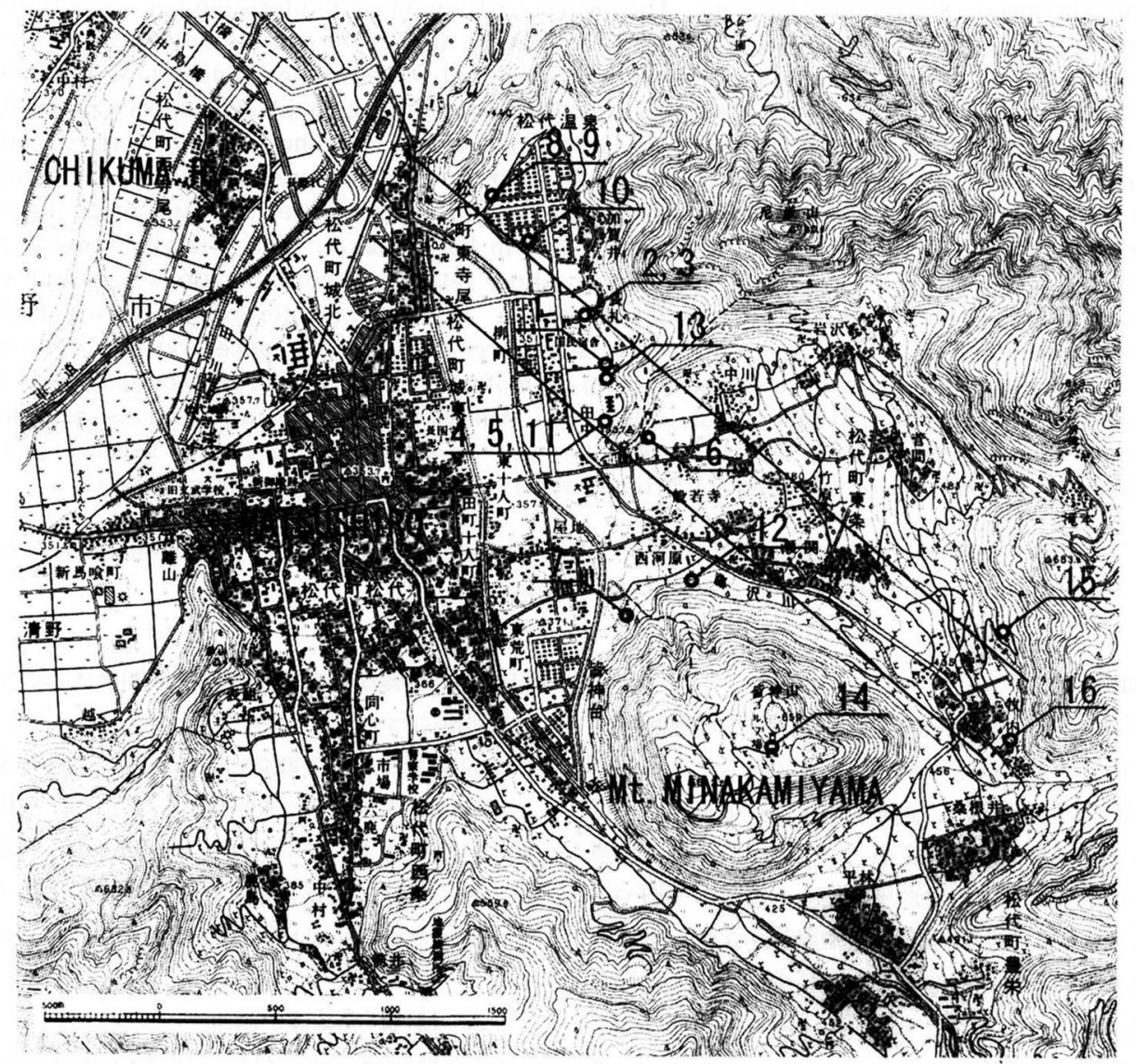

Fig. 1. Locations of measurement points (O). Each number corresponds to that in Table 1. The area between two lines indicates a zone of the buried Matsushiro earthquake faults. Base map is 1 : 25,000 "Matsushiro" topographic map issued by the Geographical Survey Institute. 
は, 地表付近の通常の循環水とは全く異なり, 極めて高 濃度の $\mathrm{Ca}^{2+}, \mathrm{Cl}^{-}$, を主要溶存成分とする特異な地下水 である [KITANo et al. (1967), YoshioKa et al. (1970)].

（2）「水の起源」に関しては，化石海水，マグマ起源 の水, 脱水反応による岩石から放出された水 [大竹 (1976)]，マントル・ダイアピルの上昇・冷却により放 出された水 [WAKITA et al. (1978)], 下部地殼に存在す る多量の水 [笹井 (1995)] などのモデルがあり, それぞ れ起源水の存在する「深さ」についても様々であるが, 地表付近の通常の水循環では説明されないものであると いう点では一致する.

（3）当初は, 水が地震発生の原因であるのか, あるい は地震発生の原因は他にあり, 地震が起こったことによ り水がもたらされたのかについては議論を呼んだ. 現在 では, 水は結果でなく, 次のように原因であるという主 張 [中村 (1971)] の方が有力である.

まず, 地下深部の高圧の水が, 何らかの原因により松 代地域の地下に供給された。この水は高圧であるがゆえ に, 地下岩石中のクラックを押し拡げ, 岩石の摩擦を弱 め, 地震を引き起こす。一方, 地下深部の水は微小ク ラックを拡げつつ地表に向かうため, 地表においては地 盤隆起などの地変をもたらし, 最終的には地表に大量に あふれ出すことになった，また，地形によっては地滑り を発生させた。

松代群発地震の原因となった地下深部の水はいわば 「深層水」であるが，地下水を扱う分野では数十 $\mathrm{m}$ 程度 の深さの地下水でも「深層水」と呼ぶことがあるので, これと区別するために, 松代地域の，おそらく少なくと あ $2 \mathrm{~km}$ 以深に存在するこの特異な深層高濃度塩水を, この論文では特に区別する必要がある際には「深部源 水」と呼ぶことにする.

\section{§3. 調查涌水について}

1965 年に松代群発地震が始まる以前にも, 松代地域 には湧水・温泉が存在した，例えば現在の加賀井温泉 は, 現在と泉源こそ異なるが, 鎌倉時代にはすでに浴用 として使われていたようであり, また, 江戸時代には農 耕地に湧き出る悪水の処理を藩に願い出たという記録が あり [青山 (1980-1981)]，かなり古くからこの地域には 普通の地下水とは異なる特殊な水が湧出していたようで ある.

このような松代群発地震以前から存在する湧水・温泉 は, 群発地震の際にはその湧出量・性状に大きな変化が みられた. また, 群発地震の最盛期には, 震源域付近に 新たに大量の湧水が地面のいたるところから涌出した. さらに, 地震による影響（渇水・泉温低下など）や調査
のために当時新たに掘削された泉源・井戸あある.しか し, 排水設備がその後整えられたこともあって, 現在で あ残っている湧水は, その数も湧出量も最盛時と比較す れば極めて少ない。

Fig. 1 は松代群発地震地域において現在も湧出を続け ていることが確認できた湧水（ボーリング孔からの自噴 温泉を含む）である.これら涌水は Fig. 1 に示すように 松代地震断層と呼ばれる伏在断層帯 [NAKAMURA and TUNEISHI (1967)] の直上および周辺に多く点在してい る.これら涌水のすべてを調査観測定点とした. Table 1 に各涌水の概要を示す. 松代荘 (Table 1 の No. 1), 加 賀井温泉一陽館 1 号源泉 (No. 2), 同 3 号源泉 (No. 3), 温 泉団地 1 号井 (No. 8), 同 2 号井 (No. 9), 松代温泉公民館 (No. 10) は, 掘削ボーリング孔からの自噴井であり, 他 の湧水に比較して水源が深い, 一方, 松井の泉 (Table 1 の No. 7), 古藻井の泉 (No. 12), 皆神山山頂池 (No. 14), 地 滑り地帯上 (No. 15), 牧内南 (No. 16) は, 地表浅層水の 影響が極めて高いと考えられる湧水である. Table 1 に 示す湧水のうち, 松代荘, 加賀井温泉一陽館 1 号源泉, 同 3 号源泉, 尚和寮 (1), 同 (2), 替依比売命神社前, 松井 の泉の 7 箇所（Table 1 の No. 1 から No. 7, 以下この文 章では, 主要 7 湧水之呼ぶ）については, 季節変化等の 長期的時間变化の有無を調べるために, 1994 年 4 月よ り 12 月まで原則として毎週一回, 定期的に測定・採水 を行った．さらに他の涌水を含むすべての観測定点（以 下，16 湧水と呼ぶ）では, 1994 年より 1997 年まで不 定期に採水・測定した.

\section{§4. 分析方法}

各調查観測定点について, 現地において, 水温 (アル コール温度計) ・電気伝導度 (東亜電波株式会社製 CM$14 \mathrm{P}$ を使用)・pH（東亜電波株式会社製 HM-12P を使 用）の測定, 試水の採取を行い, 実験室で試水の溶存主 要イオンの定量をイオンクロマトグラフィにより行った (使用機器は横河アナリティカルシステムズ社製イオン クロマトグラフ IC7000E). '定量イオンは, $\mathrm{F}-\mathrm{Cl}^{-}$, $\mathrm{NO}_{2}^{-}, \mathrm{Br}^{-}, \mathrm{NO}_{3}^{-}, \mathrm{PO}_{4}^{3-}, \mathrm{SO}_{4}^{2-}, \mathrm{Li}^{+}, \mathrm{Na}^{+}, \mathrm{NH}_{4}^{+}, \mathrm{K}^{+}, \mathrm{Ca}^{2+}$, $\mathrm{Mg}^{2+}$ である. 陽イオン分析には, ICS-C25, 陰イオン分 析には, ICS-A23 カラムを使用し, 溶離液は同社のマ ニュアルに沿って調整した。陰イオンは $3 \mathrm{mM}-\mathrm{Na}_{2} \mathrm{CO}_{3}$ を溶離液, $15 \mathrm{mM}-\mathrm{H}_{2} \mathrm{SO}_{4}$ を除去液としたサプレッサ法 で, また, 陽イオンは $5 \mathrm{mM}$-酒石酸と $1 \mathrm{mM}$-ピリジン 2.6- ジカルボン酸の混合溶液を溶離液としたノンサプ レッサ法でそれぞれ分析した. いずれの測定において あ, 試料量は $50 \mu l$, 溶離液の流速は, $1 \mathrm{ml} / \mathrm{min}$, 恒温槽 は $40^{\circ} \mathrm{C}$ とした. 同一試料のくり返し測定による定量值 
Table 1. Measurement points (each number corresponds to that in Fig. 1).

\begin{tabular}{|c|c|c|c|c|}
\hline No. & measurement point & well depth (m) & time $\left(^{*}\right)$ & description \\
\hline 1 & Matsushiroso well & 600 & $\mathrm{C}$ & \\
\hline 2 & Ichiyokan well No. 1 (B) & 86 & A (1930) & \\
\hline 3 & Ichiyokan well No. 3 (C) & 122 & B (1967) & $\begin{array}{l}\text { water seems to be a mixture of wa- } \\
\text { ter from the bottom and that from } \\
\text { damaged points of casing pipe at shal- } \\
\text { low depth. }\end{array}$ \\
\hline 4 & Showaryo spring No. 1 & Unknown & B & $\begin{array}{l}\text { a spring appearing in front of the } \\
\text { gate of Showaryo in the rice field. }\end{array}$ \\
\hline 5 & Showaryo spring No. 2 & & $\mathrm{~B}$ & $\begin{array}{l}\text { one of the springs appearing on the } \\
\text { foot of a hill, } 50 \text { m east from the Sho- } \\
\text { waryo spring No. } 1 \text {. }\end{array}$ \\
\hline 6 & Tamayorihimenomikoto-Jinjamae & & B & $\begin{array}{l}\text { a spring appearing in front of the } \\
\text { gate of Tamayorihimenomikoto- } \\
\text { Shrine. }\end{array}$ \\
\hline 7 & Matsuinoizumi & & A & $\begin{array}{l}\text { one of the springs on the foot of the } \\
\text { Mt.Minakamiyama. }\end{array}$ \\
\hline 8 & Onsendanchi well No. 1 & 30 & $\mathrm{C}$ & \\
\hline 9 & Onsendanchi well No. 2 & 360 & $\mathrm{C}$ & \\
\hline 10 & Matsushiro-Onsenkominkan & Unknown & $\mathrm{C}$ & $\begin{array}{l}\text { hot water in the bathroom in the } \\
\text { community center, piped from a hot } \\
\text { spring. }\end{array}$ \\
\hline 11 & Showaryo spring No. 3 & & B & $\begin{array}{l}\text { one of the springs appearing on the } \\
\text { foot of a hill, } 50 \mathrm{~m} \text { east from the } \\
\text { Showaryo spring No. } 1 \text {, } \\
10 \mathrm{~m} \text { north from the Showaryo No. } 2 \text {. }\end{array}$ \\
\hline 12 & Komoinoizumi & & A & $\begin{array}{l}\text { one of the springs on the foot of the } \\
\text { Mt. Minakamiyama. }\end{array}$ \\
\hline 13 & Ichiyokan-Minami & Unknown & B & $\begin{array}{l}\text { a spring appearing in a farm, a short } \\
\text { concrete pipe is fixed. }\end{array}$ \\
\hline 14 & Minakamiyama-Sancho-Ike & & Unknown & $\begin{array}{l}\text { a pond at the top of Mt. Minakami- } \\
\text { yama. }\end{array}$ \\
\hline 15 & Jisuberichitai-Ue & & B & $\begin{array}{l}\text { one of the springs in the Makiuchi- } \\
\text { landslide area. }\end{array}$ \\
\hline 16 & Makiuchi-Minami & & A & $\begin{array}{l}\text { one of the springs in the landslide } \\
\text { area. }\end{array}$ \\
\hline
\end{tabular}

No. 1-7: Samples collected on every Wednesday during Apr. 1994-Dec. 1994.

No. 8-13: Samples collected at irregular intervals during 1994-1997.

$(*)$ time: date of water eruption starting
A: Before Aug. 1965
B: Between Aug. 1965 and May 1967
C: After May 1967

の再現性は, 相対標準偏差の最大值は, 陰イオンでは $\mathrm{Br}^{-}$で $0.3 \%$, 陽イオンでは $\mathrm{Mg}^{2+}$ で $2.2 \%$ あった. なお, 調査涌水によっては, イオン濃度が高く使用機器 のカラムを傷めるおそれがあるため, 電気伝導度が 1 $\mathrm{mS} / \mathrm{m}$ 以下になるように 10〜 100 倍に希釈してから測 定を行った.

なお，今回分析に使用した機器では，天然水中の主要 陰イオンである $\mathrm{HCO}_{3}^{-}$が分析できない，通常, 天然水が 電気的に中性であるという仮定から導かれる残留陰イオ
ン濃度 (総陽イオン濃度-総陰イオン濃度) を, 近似的に $\mathrm{HCO}_{3}^{-}$濃度と見なすことが多いが (Table 2 参照), 松代 群発地震地域の湧水には, $\mathrm{Fe}^{2+}, \mathrm{Fe}^{3+}$ なども無視でき ない量含まれ, $\mathrm{Fe}^{2+}, \mathrm{Fe}^{3+}$ それぞれの定量は今回の測定 機器ではできないので, この方法からも $\mathrm{HCO}_{3}^{-}$濃度は 定量し得ない. $\mathrm{HCO}_{3}^{-}$イオンは不安定なのでその濃度は 試水取得後すぐに分析しなくてはならず, $\mathrm{HCO}_{3}^{-}$濃度測 定手法として一般に用いられるアルカリ度测定には，上 述の他イオンの測定手法に比べて多量の試水を必要とす 
ることから，今回は $\mathrm{HCO}_{3}^{-}$濃度の測定は見送った。

\section{§5. 湧水の定量分析結果}

\section{1 経時変化}

Fig. 2 に観測定点の一つである松代荘（源泉深度 600 m）の，9ヶ月間にわたって週一回行った測定の結果を
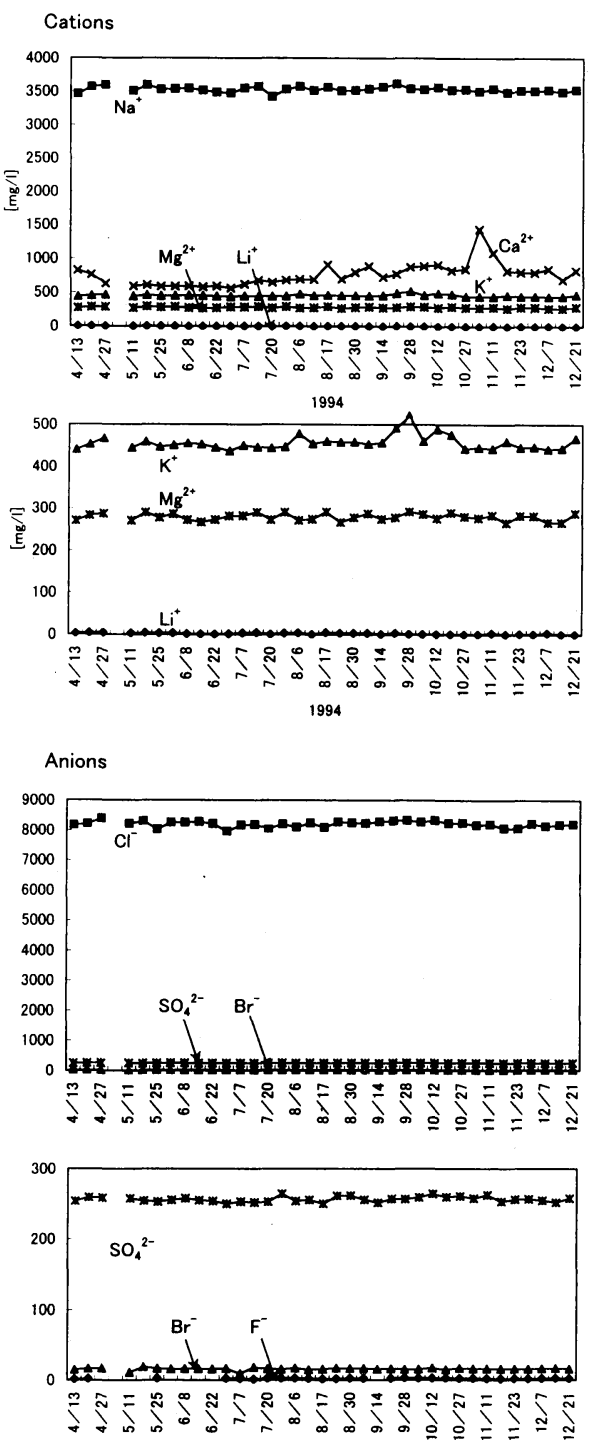

Fig. 2. Temporal variation in the concentrations of major ions with time in the ground water from the $600 \mathrm{~m}$ deep Matsushiroso well in the period from Apr. 1994 to Dec. 1994. The second graph from the top is the expanded one of the top graph. The bottom graph is the expanded one of the third.
示す．水温およびほとんどの溶存イオン濃度は, 調査期 間中ほとんど一定であり，この 9 ヶ月間に時間的変化は 認められない.ただし, $\mathrm{Ca}^{2+}$ 濃度は他のイオン濃度に比 較して変化が大きく，また調査期間を通じて若干の増加 傾向が見られる。このような，水温およびほとんどの溶 存イオン濃度が調査期間中一定で, $\mathrm{Ca}^{2+}$ 濃度のみ若干 の変化があるという傾向は, 松代荘以外の主要 7 湧水に ついても同様である (Table 2).

また，この 9 ヶ月間の調査の後，1995 年〜1997 年に 不定期に行った調查においても，16 湧水の各溶存イオ ン濃度には, 主要 7 湧水の 9 ヶ月間に見られた程度の変 化しか見られなかった。

\section{2 湧水によるイオン組成の䢖い}

Table 2 は, 各調査湧水（16 涌水）の定量分析結果で ある. 1994 年に行った 9 ヶ月間の調査の, 各湧水の調 査回数・平均值・標準偏差を示している.

多くの調査湧水は, 陽イオンでは $\mathrm{Na}^{+}$濃度, $\mathrm{Ca}^{2+}$ 濃 度が高く，陰イオンでは $\mathrm{Cl}^{-}$が圧倒的に高い，松代群発 地震を引き起こした水が， $\mathrm{CaCl}_{2}$ 型であるといわれるゆ えんである.しかし, 松代荘, 一陽館, 松代温泉公民館, 温泉団地など，泉源が深いボーリング孔からの湧水 (Table 1 参照) では, 他の浅い湧水に比較して $\mathrm{Ca}^{2+}$ 濃 度の比が低下し, $\mathrm{Na}^{+}$濃度が高くなっている．また, $\mathrm{K}^{+}$ 濃度も比較的高い. 反対に，泉源が浅いと思われる湧水 では, $\mathrm{Ca}^{2+}$ 濃度が陽イオンの中で占める割合が増加し， $\mathrm{Mg}^{2+}$ 濃度も高くなる傾向がある，陰イオンでは，松井 の泉, 古藻井の泉, 皆神山山頂池, 地滑り地帯上, 牧内 南など地表浅層水の影響が極めて高いと考えられる湧水 は, $\mathrm{SO}_{4}^{2-}$ が多く溶存しているが，概して $\mathrm{Cl}^{-}$濃度が圧 倒的に高い.

なお, 前述したように, 総陽イオン濃度一総陰イオン濃 度 (Total Cat.-Total Ani.) を, 近似的に $\mathrm{HCO}_{3}^{-}$濃度之 見なすことはできるが, 松代荘, 一陽館では総陰イオン 濃度の方が総陽イオン濃度より屯高くなっている。これ らの泉源は特に深く，今回定量されないイオン（例えば $\mathrm{Fe}^{2+}, \mathrm{Fe}^{3+}$ など）の奇与が高いためと考えられる。この ため $\mathrm{HCO}_{3}^{-}$についての議論は行わなかった.

\section{§ 6. 群発地震発生時から現在までのイオン潾度の変} 化

前節で述べたように，現在（1994 年〜1997 年）の松 代群発地震地域の湧水は, 湧水量, 主要イオン濃度・組 成ともにかなり安定した状態にあるといえる。こうした 傾向はいったいいつからのものなのであろうか.

加賀井温泉一陽館 1 号源泉 (Fig. 1, Table 1, 2 の No. 2) は, 松代群発地震の発生前から存在する源泉であり 


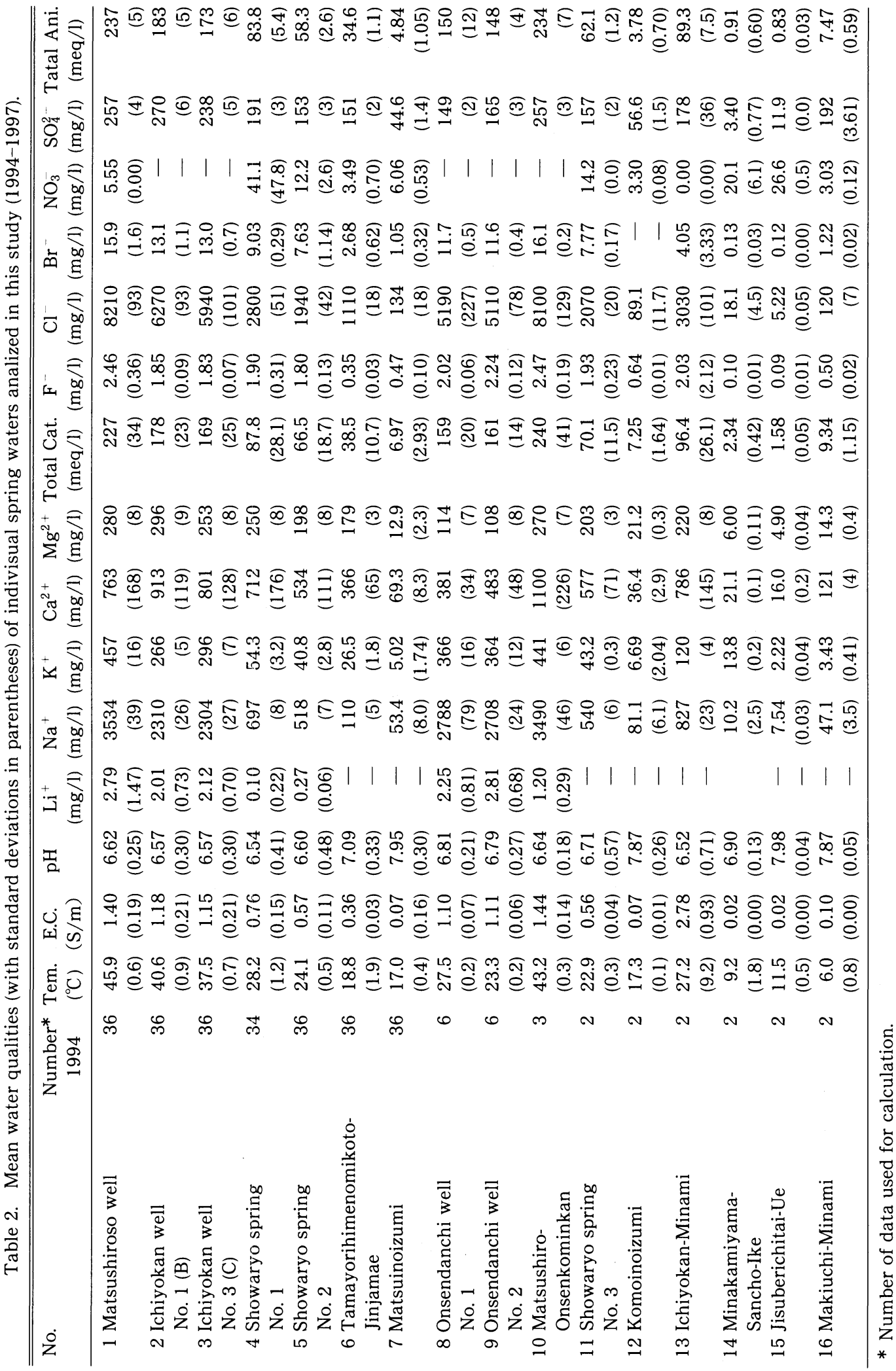


(1964 1965 年の間は涸渇), 1930 年に温泉分析書が 作成されている.これによると，この源泉の $\mathrm{Cl}^{-}$濃度は 現在の約半分の $2359 \mathrm{mg} / l(\fallingdotseq 67 \mathrm{meq} / l)$ であったこと がわかる.

Fig. 3 は松代群発地震が最も活発であった 1966 年〜 1967 年当時の, 同源泉における $\mathrm{Cl}^{-}$濃度の変化の様子 を示したものである [野口・他(1969)]. 群発地震が始 まってほぼ一年後の 1966 年 9 月頃を境に, 約 1500 $\mathrm{mg} / l(\fallingdotseq 42 \mathrm{meq} / l)$ であったものが，おおよそ半年の間 に約 $5000 \mathrm{mg} / l(\fallingdotseq 141 \mathrm{meq} / l)$ 以上にまで急上昇した 様子が見て取れる.（群発地震のごく初期は $2535 \mathrm{mg} / l$ （1965年 11 月 3 日）であり, その後しばらく減少, 最 低で $1200 \mathrm{mg} / l(1966$ 年 3 月 31 日, 同 4 月 10 日) を 記録した [野口・他 (1969), 春日 (1976)].このときは第 2 活動期のピークであった. )

1966 年 9 月という時期は, 群発地震の第 3 活動期の ピークにあたり, 有感地震の回数こそ第 2 活動期より少 ないが, 松代群発地震を特徵づける地盤の隆起・伸縮, 大量の湧水, 地磁気・重力加速度の変化などの現象が最 も活発に認められた時期である.この時期に一陽館 1 号 源泉の涌出量は群発地震期間中で最大（約 $1.9 \mathrm{t} / \mathrm{min}$ ) に達し, 他の地点からも大量の地下水が地表に湧出し, 牧内地区では地滑りが発生する (9月 17 日)などの地表 変動も著しく, 重力加速度もこの時期を境に減少から増 加に転じている [大竹 (1976)].

その後, 連続的な観測はなされていないが, 不定期的 になされた観測によると，1968 年頃までの間におよそ $5500 \mathrm{mg} / l(\fallingdotseq 155 \mathrm{meq} / \mathrm{l})$ 前後まで上昇し, 以後は同程 度の值が報告されている [春日 (1976), 野口・他 (1969) など]. また, 1994 年 4 月以降は $6000 \mathrm{mg} / l$ 弱程度で 安定している. したがって, 一陽館 1 号源泉の $\mathrm{Cl}^{-}$濃度 は 1966 年 9 月頃を境に急増したが, それ以後再び以前

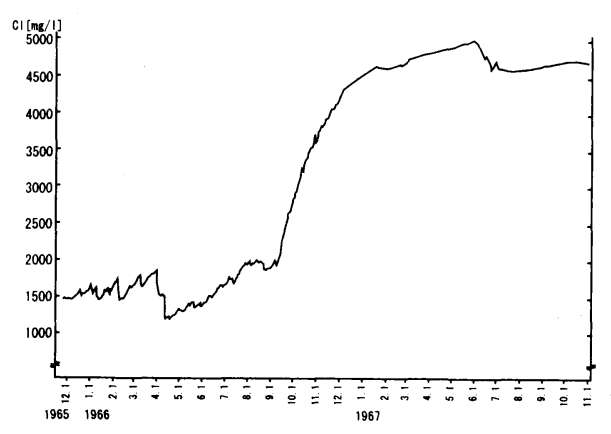

Fig. 3. Rapid increase in $\mathrm{Cl}^{-}$concentration at the Ichiyokan well (No. 1) in the period from 1966 to 1967 (after Noguchi et al., 1969).
の状態に戻ることなく, 1968 年頃には以前より高い值 で安定した状態で現在に至っているといえよう.

一方, 鶴見 (1979) は, 加賀井温泉の $\mathrm{Na}^{+} / \mathrm{Mg}^{2+}$ 比に 注目し, 1965 年 3 月（群発地震のはじまる前）・1965 年 11 月 (発生期間中) ・1977 1978 年 (地震後) の 3 種類のデータを比較した. その結果, 同温泉の $\mathrm{Na} / \mathrm{Mg}$ 比が地震後大きく減少したことを明らかにした. その変 化の原因として鶴見 (1979) は, この地域の地下水を構 成する二種類の水の混合比率が地震以降変化した, と述 べた.この二種類の水のうち, 現在多い比率で見られる 水は, 二酸化炭素が地下で水に溶けて岩石と反応し $\mathrm{Ca}^{2+}$ や $\mathrm{Mg}^{2+}$ に富んだ水である, としている. 現在 (1999 年) 同温泉の $\mathrm{Na} / \mathrm{Mg}$ 比はおよそ 4.5 で, 鶴見 (1979)による地震後のデータとほぼ同程度であり, 同論 文に述べられている地震によって生じた減少はその後再 び増加することなく安定しているといえよう.

以上のことから, 地震発生後 1968 年頃から現在にか けては, 加賀井温泉では主要イオン $\mathrm{Cl}^{-}$濃度及び $\mathrm{Na}^{+} /$ $\mathrm{Mg}^{2+}$ 比は，ともに大きな変化はしていないと推定でき る.

では，加賀井温泉以外の湧水の変化はどのようなもの であったのであろうか. 加賀井温泉以外の湧水において は定点観測を長期的に行った調查はあまりないが, YoSHIOKA et al. (1970) は, 松代群発地震地域の五つの涌水 で, 1966 年 9 月から 1969 年 1 月までひと月に一回の 主要溶存イオンの定量観測を行っている.これによる と, どの湧水も 1967 年の前半までは各種溶存イオン濃 度に変化が見られるが, 三つの湧水では, こうした変化 む 1968 年になる頃には，ほぼ安定している．他の二つ はその後も変化が見られるが, このうち一つは表層水の 影響が大きいためであろうとしている.

この他, 松代群発地震地域の湧水の溶存イオン濃度に ついての調査はいくつかあるが, 調査報告により各涌水 の表記がまちまちであるため, 同一の湧水であるという 確認が難しい. 同定し得たものについては, 1968 年以 降の調査で我々の調査による定量值と大きく異なったも のはなく, したがって, 1968 年以降, 松代群発地震地域 の湧水は, 表層水の影響が大きいものを除き，おおよそ 安定した状態になったと考えられる.

\section{§ 7. 考察 \\ $7.1 \mathrm{Ca}^{2+}$ 壊度を支配するメカニズム \\ 7.1.1 $\mathrm{Ca}^{2+}$ 湌度の特徽}

$\mathrm{Ca}^{2+}$ に関しては, 他の溶存イオンと異なる二つの特 徴がある.

（1）すでに述べたように，1968 年頃から松代群発地 
震地域の湧水はほとんどの溶存イオン濃度に関して大き な変化をしていない，このことは, 各湧水の水源となる 帯水層がほぼ安定した状態に落ち着いたものと考えられ る. ただし, 湧水中の $\mathrm{Ca}^{2+}$ 濃度のみは, 9 ヶ月間の測定 結果である Fig. 2 にも示されるように, 他の溶存イオン に比較して, 特に調查期間後半においてその時間変化が 大きい.

Fig. 4 は現在の各湧水の, $\mathrm{Cl}^{-}$と $\mathrm{Ca}^{2+}$ との関係を示 したものである. 1994 年に 7 つの湧水 (Fig. 1 の No. 1 〜 の 湧水) で行った 9 ヶ月間一週間ごとの測定値であ る. $\mathrm{Cl}^{-}$濃度はほぼ一定であるのに対して, $\mathrm{Ca}^{2+}$ 濃度の 時間変化が大きいため, 各湧水について上下に変動幅の あるグラフとなる。一方, $\mathrm{Cl}^{-}$と $\mathrm{Na}^{+}, \mathrm{K}^{+}, \mathrm{Br}^{-}$などとの 関係では, 上に述べたように両イオンの濃度は現在ほと んど安定しているため, 1994 年の全測定值を示しても 各々の湧水はそれぞれ一つの点にほぼ収束する。

(2) $\mathrm{Ca}^{2+}$ は変動幅だけでなく, $\mathrm{Cl}^{-}$との関係では $\mathrm{Cl}^{-}$濃度が高い湧水で $\mathrm{Ca}^{2+}$ 濃度が低くさえなっている (Fig. 4). 全体としてみれば, $\mathrm{Ca}^{2+}$ 濃度は一陽館 1 ・3 号 源泉 (深度 $86 ・ 122 \mathrm{~m}$ ) で最も高く, 松代荘 $(600 \mathrm{~m})$ は それよりも低い濃度となって現れている。

\subsection{2 $\mathrm{Ca}^{2+}$ の溶出機構}

松代群発地震発生以後, この地域では, 地表自噴湧 水・ボーリング孔からの温泉水など, 地下水に関して数 多くの分析がなされている. Fig. 5 は松代群発地震地域 における地下水の, 群発地震当時から現在までになされ た分析の結果を $\mathrm{Cl}^{-}$と $\mathrm{Na}^{+}$の関係について示したもの である.

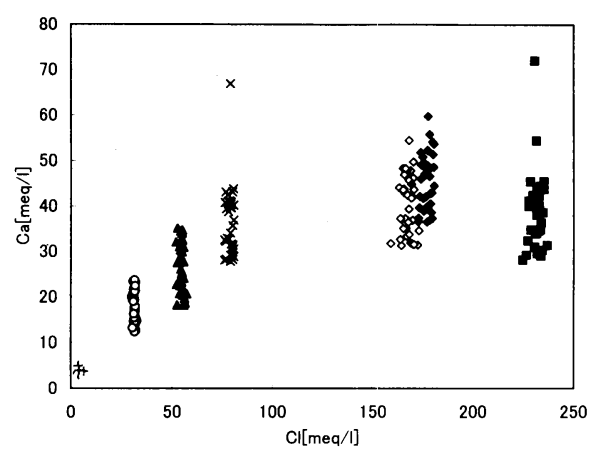

Fig. 4. Plots of $\mathrm{Ca}^{2+}$ content against $\mathrm{Cl}^{-}$content in ground waters in the period from Apr. 1994 to Dec. 1994. ㅁ: Matsushiroso, $\checkmark$ : Ichiyokan well No. $3, \diamond$ : Ichiyokan well No. 1, $\times$ : Showaryo spring No. 1, Showaryo spring No.2, $\bigcirc$ : Tamayorihimenomikoto-Jinjamae, and +: Matsuinoizumi.

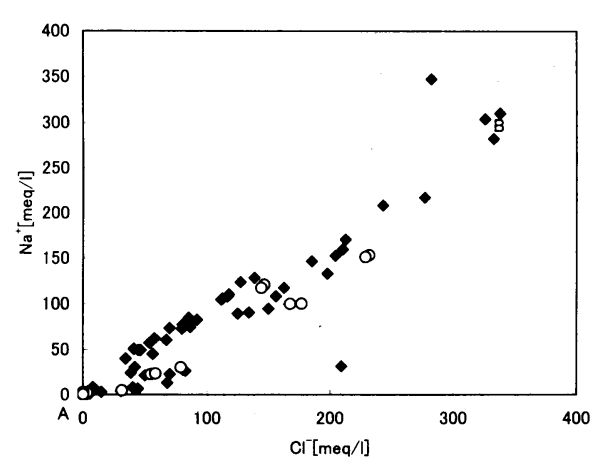

Fig. 5. Plots of $\mathrm{Na}^{+}$content against $\mathrm{Cl}^{-}$content. "A" is a point of $\mathrm{Na}^{+}=0 \mathrm{meq} / l$ and $\mathrm{Cl}^{-}=0 \mathrm{meq} / l$. "B" is a point of averaged values of $\mathrm{Na}^{+}$and $\mathrm{Cl}^{-}$of Matsushiroso $1800 \mathrm{~m}$ borehole data (Geol. Surv. Japan. 1979a.). $\bigcirc$ : Our data on 14 Dec. 1994, and ४: Data after Geol. Surv. Japan. [1979a,b], Kakegawa [1968], Kasuga [1976], Kitano et al. [1967], Matsushiro Public Health Center [1967a,b,c], NoGUCHI [1967], NoGUCHI [1968], Noguchi et al. [1969], Noguchi et al. [1970], TSURUmi [1979] and UMEMURA and HARADA [1968a,b].

Fig. 5 において, A は原点であり, $\mathrm{B}$ 付近の 3 点は後 述する松代荘 $1800 \mathrm{~m}$ 深層ボーリング試験（我々の調査 による松代荘の泉源とは異なる）のデータである（地質 調查所 (1979b), Table 3). 各地下水の $\mathrm{Na}^{+} / \mathrm{Cl}^{-}$の值は おおよそ A-B 直線上に並ぶ.すなわち, 最も単純に考え れば, $\mathrm{Na}^{+}$濃度と $\mathrm{Cl}^{-}$濃度に関しては, 深部源水と浅層 低濃度水が様々な割合で混合しあい, 各湧水が形成され ているということになるが, $\mathrm{Na}^{+}$濃度が下方にばらつい ているのが目につく.そこで, $\mathrm{Na}^{+}$濃度の代わりに $\mathrm{Na}^{+}$ 濃度 $+\mathrm{Ca}^{2+}$ 濃度を縦軸に, $\mathrm{Cl}^{-}$濃度を横軸にとって示 したものが Fig. 6 である. 縦軸のばらつきが Fig. 5 と 比較して格段に小さくなっているのがわかる。これは, 地下水が地下岩石中を上昇する間, 周囲の岩石と反応 し, $\mathrm{Ca}^{2+}$ を溶出すると同時に $\mathrm{Na}^{+}$が吸着された結果だ と見ることができる. $\mathrm{Na}^{+}$と $\mathrm{Ca}^{2+}$ のイオン交換が行わ れているのである.これにより, 上記 $\mathrm{Ca}^{2+}$ 濃度の特徴 の (2) が現れていると理解される.

以上は, 佐竹・村田 (1998) が茂住断層内の地下水を 茂住断層調查坑道で採取して分析した結果, 断層中心部 では $\mathrm{Na}^{+}$濃度が高いが, 周辺部では $\mathrm{Ca}^{2+}$ と交換し, $\mathrm{Na}^{+}$濃度は低くなり, $\mathrm{Ca}^{2+}$ 濃度が高くなるという事実 と調和的である. また, YoshiokA et al. (1970) も, 塩水 と粘土との反応により $\mathrm{Na}^{+}$が吸着され, $\mathrm{Ca}^{2+}$ が溶出 し, 水質は $\mathrm{CaCl}_{2}$ 型に変質してゆくと指摘している. 
なお, Fig. 7 に, Fig. 5 の $\mathrm{Na}^{+}$濃度の代わりに $\mathrm{Ca}^{2+}$ 濃度にしたものを示す。ここで, $\mathrm{Cl}^{-}$濃度が $250 \mathrm{meq} / \mathrm{l}$ 以上の高いものは, ボーリング孔からの湧水で，その水 源が深いものである (600 $\mathrm{m}$ 以上). あし深部源水が $\mathrm{CaCl}_{2}$ 型であるとすると, これらの $\mathrm{Ca}^{2+}$ 濃度はかなり 高いあのになるはずであるが, 実際には, 他の湧水に比 較して, 低くさえなっている.

また, Yoshioka et al. (1970) は, 同一涌水における各 種溶存イオンの経時観測を行っている. その結果は, 数 值が公表されていないが，グラフから読むと 1966 年〜 1968 年まで $\mathrm{Na}^{+}, \mathrm{Ca}^{2+}, \mathrm{Cl}^{-}$の濃度がそれぞれ同期して 変化している. しかし, この間 $\mathrm{Na}^{+}+\mathrm{Ca}^{2+}$ と $\mathrm{Cl}^{-}$のイ オンバランスがほぼとれているようであり, 時間的に $\mathrm{Na}^{+}, \mathrm{Ca}^{2+}, \mathrm{Cl}^{-}$のイオン濃度は変化しても, $\mathrm{Na}^{+}+$ $\mathrm{Ca}^{2+}$ と $\mathrm{Cl}^{-}$のイオンバランスはこの時期には変化しな かったことがわかる.

ところで, 上記 $\mathrm{Ca}^{2+}$ 濃度の特徴の (1) で述べたよう に, 現在それぞれの湧水一つ一つの時間変化についてみ ると, $\mathrm{Ca}^{2+}$ 濃度は変化しているにも関わらず $\mathrm{Na}^{+}$濃 度, $\mathrm{Cl}^{-}$濃度はほとんど変化をしていない，つまり， $\mathrm{Na}^{+}+\mathrm{Ca}^{2+}$ と $\mathrm{Cl}^{-}$のイオンバランスがとれておらず, このことから現在の湧水の $\mathrm{Ca}^{2+}$ 濃度の時間変化は, 1 オン交換とはさらに別の機構により変化しているものと 考えられる. 例えば $\mathrm{Ca}^{2+}$ は水-岩石反応で, $\mathrm{CO}_{2}$ の存在 下で $\mathrm{Ca}^{2+}$ と $\mathrm{HCO}_{3}^{-}$を生じ比較的容易に濃度が変化す ることが知られている.すすなお，

$$
\mathrm{CaCO}_{3}+2 \mathrm{CO}_{2}+\mathrm{H}_{2} \mathrm{O} \rightleftarrows \mathrm{Ca}^{2+}+2 \mathrm{HCO}_{3}^{-}
$$

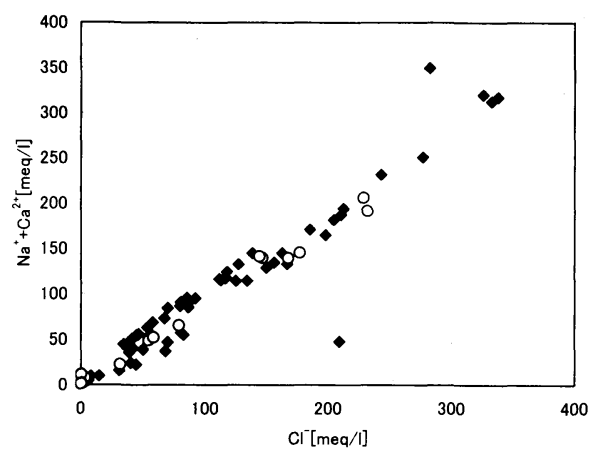

Fig. 6. Plots of $\mathrm{Na}^{+}+\mathrm{Ca}^{2+}$ content against $\mathrm{Cl}^{-}$ content. $\bigcirc$ : Our data on 14 Dec. 1994, and $\checkmark$ : Data after Geol. Surv. Japan. [1979a,b], KaKegawa [1968], Kasuga [1976], Kitano et al. [1967], Matsushiro Public Health Center [1967a,b,c], Noguchi [1967], NoguchI [1968], Noguchi et al. [1969], Noguchi et al. [1970], TSURUmi [1979] and UMEMURA and HARADA [1968a,b].

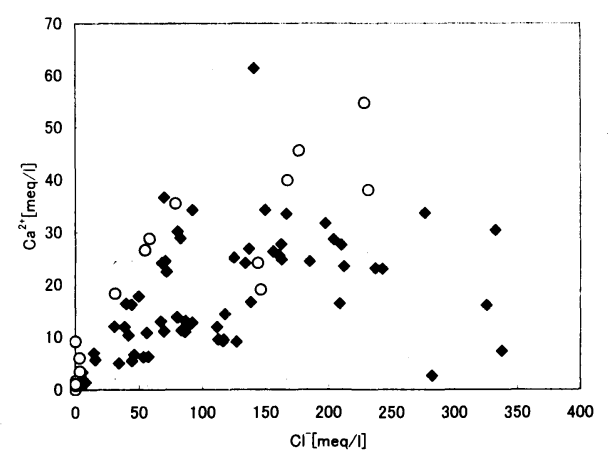

Fig. 7. Plots of $\mathrm{Ca}^{2+}$ content against $\mathrm{Cl}^{-}$content. $\bigcirc$ : Our data on 14 Dec. 1994, and $\checkmark$ : Data after Geol. Surv. Japan. [1979a, b], KaKegawa [1968], Kasuga [1976], Kitano et al. [1967], Matsushiro Public Health Center [1967a, b, c], Noguchi [1967], Noguchi [1968], Noguchi et al. [1969], NoGUCHI et al. [1970], TSURUMi [1979] and UMEMURA and HARADA [1968a, b]. The values scatter remarkably.

松代地域の湧水は大量の $\mathrm{CO}_{2}$ 遊離ガスを伴っている ので [清水・他 (1998)など], $\mathrm{CO}_{2}$ 圧はこの地域の地下 で高いことはわかっている. また, 松代地域の地層中に は, $\mathrm{CaCO}_{3}$ がごく普通にみられる（1969 年に松代荘の 敷地内で実施された $1800 \mathrm{~m}$ 調査ボーリングの際には, 松代群発地震地域の地下には方解石脈が著しく発達して いることが確認された[高橋(1970)]). したがって $\mathrm{CaCO}_{3}$ を溶かして $\mathrm{Ca}^{2+}$ が $\mathrm{Na}^{+}$や $\mathrm{Cl}^{-}$とは無関係に増 加することは十分考えられる. しかし, $\mathrm{HCO}_{3}^{-}$の定量分 析はしていないので, 確認はできない.

このように, 現在の地表湧水で見られる $\mathrm{Ca}^{2+}$ 濃度は, 前者のように $\mathrm{Na}^{+}$と $\mathrm{Ca}^{2+}$ とのイオン交換によるもの と, 後者のように高い $\mathrm{CO}_{2}$ 圧の下で鉱物から溶出した あのとがあると考えられる. Fig. 2 を見たところ, 短期 間（ここでは 9 ヶ月間）の $\mathrm{Ca}^{2+}$ の変化に対応する $\mathrm{Na}^{+}$ および $\mathrm{Cl}^{-}$変化は見られないので, 現在見られる短期間 での時間変化は, イオン交換でなく, $\mathrm{CO}_{2}$ による鉱物か らの分解・溶出が $\mathrm{Ca}^{2+}$ 濃度変化の主要なメカニズムで あろう。また，一週間程度の短い時間で細かく変化する $\mathrm{Ca}^{2+}$ 濃度の要因として, イオン交換は考えにくい.

\section{2 同一の起源水をもつ各湧水}

Fig. 6 から, 松代群発地震地域に見られる多様な湧水 は, $\left(\mathrm{Na}^{+}+\mathrm{Ca}^{2+}\right)$ と $\mathrm{Cl}^{-}$の高濃度の地下水が低濃度の地 下水と様々な割合で混合しあうことによりもたらされて いるという，二液混合モデルが強く支持される.さらに, 地表湧水に多く見られる $\mathrm{Ca}^{2+}$ は，上に述べたように， 
$\mathrm{Na}^{+}$との交換と, (1) 式反応により上乗せされたもので あり, 深部源水の陽イオンとしては, $\mathrm{Ca}^{2+}$ は低く, $\mathrm{Na}^{+}$ が主であると考えられる.

\section{3 初源的深厝水のイオン溇度の推定}

Fig. 5 の B 点に示す松代荘 $1800 \mathrm{~m}$ 深層ボーリング 試験の際に観測された水は, 松代群発地震地域において これまでに見られた水の中で最む濃度の高いものであ り，むっとも深部で採水された水である. したがってこ の水は深部源水の組成に最む近いむのと考えられる. が, さらにこの水の組成は, 以下に述べる理由によりほ ぼ深部源水そのものの組成を示しているあのと考えられ る.

松代群発地震が始まって約 4 年後, 湧水の最盛期の ピーク時 (1966 年 9 月) からは約 2 年半後の 1969 年 3 月, 松代群発地震の震源性状を調べるために, 科学技術 庁防災科学技術センター（現防災科学技術研究所）によ り, 群発地震域の中心部である松代荘構内において深層 ボーリング調査が行われた. 孔長（見かけ深度）は 1934 $\mathrm{m}$ であるが, 途中でボーリング孔が傾斜してしまったた め, 真の深度は約 $1800 \mathrm{~m}$ である，掘削中, 深度 250〜 $400 \mathrm{~m}$ で温水が強く自噴したほか, $1320 \mathrm{~m}$ で $150 \mathrm{l}$ $\min$ ほど自噴したという [高橋 (1970)]。この深度 1320 $\mathrm{m}$ 付近の地下水の分析が 3 度にわたって地質調査所に より行われている(Table 3). このうち第 3 回目の分析 試料はケーシングを施す際の孔内洗浄後のものである が，第 1 回目 (1969.9.8) および第 2 回目 (1969. 9. 12) の分析試料は，孔内洗浄前のデー夕であり [防災科学技 術センター(1970)], ほぼこの深度付近の水が採取・分 析されたものと思われる。ボーリングコアによる地質柱 状図によれば，見かけ深度 $1386 \mathrm{~m}$ 以浅は砂岩・頁岩を 主とする堆積岩であるが，それより深部は玄武岩および 閃緑岩である [高橋(1970)]。つまり深度 $1320 \mathrm{~m}$ とい
う深さは頁岩および砂岩層のうちであっとあ下部にあた り, そのすぐ下の玄武岩, 閃緑岩などの火成岩は群発地 震の発生している同じ地質と推定できる. では, この 1969 年当時における深度 $1320 \mathrm{~m}$ 付近の水とはいった いどういうものであったろうか.

群発地震前からもともと深度 $1330 \mathrm{~m}$ (深層ボーリン グ時の採水地点）付近に存在していた水は, 通常の地表 付近の浅層水に比較すれば, 各種の溶存イオンを多く溶 かしこんだかなり高濃度の深首水であったと推定でき る. しかし，さらに深部から上昇してきた，地震の引き 金となった高圧な深部源水に押し出され，当時 $1320 \mathrm{~m}$ に存在した地下水は深部源水と混ざり合いながら地表へ と追い出されていったものと考えられる. 群発地震の最 盛期にFig. 1 に示すような地域で地表のいたるところ から高濃度塩水が溢れ出したことから考えて, 当時この 高濃度塩水が湧出した地域の地下は (少なくとも $1 \sim 2$ $\mathrm{km}$ 以浅程度の浅部では), 地下水が岩石中の亀裂を比 較的自由に行き来できる状態にあったと考えられるから である. 群発地震初期 (1966 年頃) の湧水中に, あとも とこの深度付近に存在していた地下水が混入して湧出し た可能性はあるが, その後, 湧水の濃度が高い值で安定 して後 (1968 年以降) には, この深度付近は深部源水の 通路となっていたであろう。したがって，このときに， 群発地震域の中心部の深さ $1320 \mathrm{~m}$ で観測された水は, 松代群発地震を引き起こした水 (深部源水) にその溶存 イオン濃度・組成は極めて近い水であると考えられる. この水は, 特に $\mathrm{Cl}^{-}$と $\mathrm{Na}^{+}$の濃度が他のイオンに比べ て圧倒的に高く，地質調查所 (1979b)による分析結果の 1 回目と 2 回目の平均を取ると,それぞれおよそ $\mathrm{Cl}^{*}$ : $11700 \mathrm{mg} / l(\fallingdotseq 330 \mathrm{meq} / l), \mathrm{Na}^{+}: 7100 \mathrm{mg} / l(\fallingdotseq 310$ $\mathrm{meq} / l)$ である.これが深部源水の溶存イオン濃度であ ろう。さらに $\mathrm{K}^{+}, \mathrm{Ca}^{2+}, \mathrm{Mg}^{2+}, \mathrm{Br}^{-}, \mathrm{SO}_{4}^{2-}$ についても同

Table 3. Major ion concentrations in water from the Matsushiroso $1800 \mathrm{~m}$ borehole (after Geol. Surv. Japan [1979b]).

\begin{tabular}{|c|c|c|c|c|c|c|c|c|c|c|c|}
\hline & Date & $\begin{array}{l}\text { Tem. } \\
{ }^{\circ} \mathrm{C}\end{array}$ & $\begin{array}{c}\mathrm{F}^{-} \\
\mathrm{meq} / \mathrm{l}\end{array}$ & $\begin{array}{c}\mathrm{Cl}^{-} \\
\mathrm{meq} / 1\end{array}$ & $\begin{array}{c}\mathrm{Br}^{-} \\
\mathrm{meq} / 1\end{array}$ & $\begin{array}{c}\mathrm{SO}_{4}^{2-} \\
1 \mathrm{meq} / 1\end{array}$ & $\begin{array}{c}\mathrm{Li}^{+} \\
1 \mathrm{meq} / 1\end{array}$ & $\begin{array}{c}\mathrm{Na}^{+} \\
\mathrm{meq} / 1\end{array}$ & $\begin{array}{c}\mathrm{K}^{+} \\
1 \mathrm{meq} / 1\end{array}$ & $\begin{array}{c}\mathrm{Ca}^{2+} \\
1 \mathrm{meq} / 1\end{array}$ & $\begin{array}{c}\mathrm{Mg}^{2+} \\
1 \mathrm{meq} / 1\end{array}$ \\
\hline Matsushiroso $1800 \mathrm{~m}$ drilling & 08-Sep-69 & 60 & - & 326 & - & 4 & - & 304 & 19 & 16 & 22 \\
\hline Matsushiroso $1800 \mathrm{~m}$ drilling & $12-$ Sep-69 & 74 & - & 338 & - & 4 & - & 311 & 21 & 7 & 25 \\
\hline Matsushiroso $1800 \mathrm{~m}$ drilling & 15-Jan-70 & & - & 333 & - & 3 & - & 283 & 8 & 30 & 12 \\
\hline
\end{tabular}

Table. 4 Estimated concentrations of major ions in original ground deep water which might have caused the earthquakes.

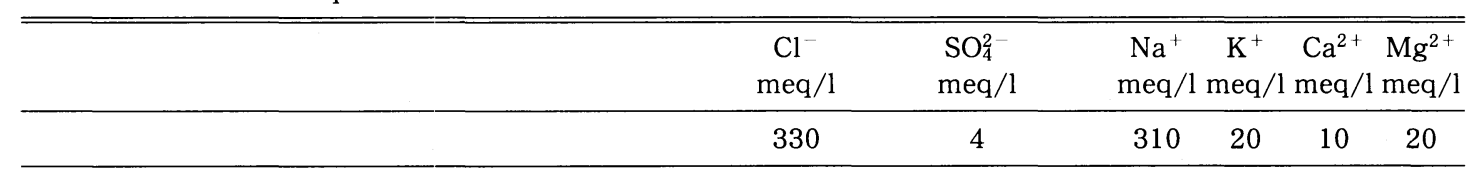


様にして推定したものを Table 4 に示す.

\section{4 初源的深槅水の起源}

松代群発地震地域に見られる地下水の $\mathrm{Na} / \mathrm{Cl}$ 比 (Fig 5 参照）は，現在の湧水も過去にみられた地下水におい ても，海水のそれとよく似た值を示し，このことから深 部源水の起源が化石海水であるとする考えがある。 ま た，松葉谷・他 (1980) は水素・酸素同位体比により深 部源水を化石海水であるとしている. しかし，水と岩石 との反応で $\mathrm{Na}^{+}$濃度は変化するし, 酸素同位体比も変 化することはよく知られている．したがって，イオン濃 度之水素・酸素同位体比から，化石海水であるとは一概 には結論づけられない，すでに述べたように，堆積層で はなく，その下の火成岩から深部源水と考えられる水が 出現することから考えると，化石海水である可能性はむ しろ少ないのではないだろうか。

WAKIT et al. (1978) は，湧水に付随するガスの ${ }^{3} \mathrm{He} /$ ${ }^{4} \mathrm{He}$ 比がら He がマントルあるいはマグマ起源であるこ とを指摘し, 付随する水もマグマ起源ではないかと指摘 した。一方笹井 (1995) は，およそ $15 \mathrm{~km}$ 以深の下部地 殻の電気伝導度の高い層が，地下水（塩水）含有層であ ると考え，ここから湧出したものとしている．塚原・他 (1999) は，笹井 (1995) を発展させ，下部地款上面付近 の地震反射層（ブライトレイヤー）からの水ではないか と主張している。しかし，湧水そのものの中に，このこ とを直接示す情報はまだ得られていない，今後の課題と して残された。

\section{5 松代群発地震地域における深原水の㴗出機構}

以上の考察から，松代群発地震地域には，深部源水か 以下に述べるような機構で湧出していると考えられる (Fig. 8).

江戸時代，松代群発地震地域に悪水が出たという記録 にあるように [青山 (1980-1981)], 群発地震発生以前に もこの地下には, 通常の地下水と異なる特殊な水一深部 源水一が存在し, 上昇・湧出していた. 群発地震に先 立って，深部源水は何らかの原因で内部圧が高まり，地 下岩石中の微小なクラックを伝って周囲に浸透し, 微小 クラック中の水压が上昇した（クラックの大きさは不明 であるが，クラックを含んだ松代断層帯では， OHTAKE (1974) による推定では透水係数が $0.01 \sim 0.1$ darcy 程度 とされている.）．クラック内面に対する有効法線応力が 低下し，摩擦抵抗力が低下するため，地下の応力状態に 応じクラック面で滑りを生じ，結果として小規模の地震 が数多く発生した. Fig. 8 に示すように，深部源水は微 小クラックを通じて上昇し，最終的には地表に湧出す る.この深部源水の上昇というイベントはかなりの短期 間に急激に起こった。そのため，それまで存在した地下
から地表への水の通路以外に新たな水の通路が生成さ れ, 浅層地下水を大量に押し出しながら, 地表に吹き出 した. 水の通路は地下岩石中の微小クラックであり，そ のためそれが多い断層帯の直上および周辺に最も多くの 湧水が新たに出現し, 既存の湧水は湧出量・溶存イオン 濃度ともに高くなった．群発地震の初期には上昇する深 部源水の量が膨大であったため，断層帯以外にも構造的 に弱い部分に湧水は出現したが，このような湧水はその 後まもなく消えた。深部源水の上昇量が減少し安定した ため，地下の水の通路が再び閉じたためであろう。

地表湧水に $\mathrm{Ca}^{2+}$ が多く見られるのに対し， 深部源水 の特徵は, Fig.8にも示されるように主要イオンが $\mathrm{Na}^{+}$, $\mathrm{Cl}^{-}$で, $\mathrm{CO}_{2}$ に富むというものである. $\mathrm{Na}^{+}, \mathrm{Cl}^{-}$は松代 地域の湧水にかなりの高濃度で存在するもので, $\mathrm{CO}_{2}$ は 遊離ガスとしても多くの湧水に認められる．この高濃度 塩水である深部源水が上昇し，今なおその一部は地表に 湧出しているが，この水は上昇するにつれて低濃度の浅 層地下水に混入する。このため深部源水は地表に現れる までにいわば「希釈」されて出てくることになる．松代 地域の湧水はそれぞれその溶存イオン濃度が大きく異な るが，これはそれぞれの湧水の水源となる帯水層におい ての深部源水の「希釈」度合いの相違によるあのである. また，松代群発地震の最盛期に，同一の湧水において溶 存イオン濃度が時間的に大きく变化したのも, 同様の理

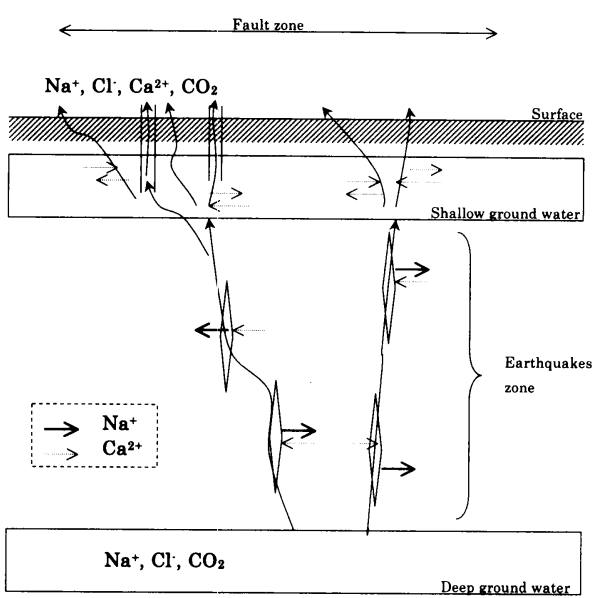

Fig. 8. A schematic drawing for explaining the variation in chemical composition of upwelling ground water. Deep ground water obtains $\mathrm{Ca}^{2+}$ from rocks and loses $\mathrm{Na}^{+}$ during its upward migration through cracks. The shallow water is enriched in $\mathrm{Ca}^{2+}$. Ground water observed on the surface is a mixture of deep and shallow ground waters with its own ratio. 
由による.

地表湧水においては，上記 $\mathrm{Na}^{+}, \mathrm{Cl}^{-}, \mathrm{CO}_{2}$ 以外に $\mathrm{Ca}^{2+}$ がかなりの高濃度で溶存しているが，その多くは 深部源水に元からあったものではなく，深部源水の上昇 過程で $\mathrm{Na}^{+}$と交換することにより溶出されたものであ ると考えられる（Fig. 8 の中央部に示す.). その交換の 程度は深部源水の通る経路により異なり，また岩石中の 滞留時間の長短にもよる. 地表湧水の主要イオン組成を 異なるものにしているのは，この $\mathrm{Ca}^{2+}$ であるが，これ は以上のように二次的にもたらされたものであるので， 深部源水の考察をする際には本質的なむのではないと考 えられる.

また，松代群発地震の期間中，地殻変動などが最大で あった時期（1966 年 9 月-第 3 活動期）には, 大部分の 湧水の各溶存イオン濃度が急激に増加したが [野口・他 (1969)など]，これは上昇を続けていた深部源水がこの 時期にいたってようやく地表に達したためであろう. 1965 年 8 月に群発地震がはじまってからほぼ一年を要 したことになる．その後はそれ以前に比較して各湧水の 帯水層での深部源水の割合が増加したため, 溶存イオン 濃度も高くなったのである。

深層水の上昇が松代群発地震を引き起こしたならば, 地震活動に付随して深層水の上昇量が変化し，それは地 表湧水のイオン濃度・組成の変化として観測されるはず である. 本研究の観測期間中, 各涌水にはほとんど変化 が認められず，また大きな地震活動もなかった．観測期 間中の微小なイオン濃度の時間変化に対応する微小地震 活動・地款変動の存否を, 松代で観測している気象庁精 密地震観測室のデータと比較検討をしたが, 対応するも のは見いだせなかった。

\section{§8. ま と め}

本研究では, 湧水の溶存イオン濃度・組成の地域によ る違いおよび経時変化を観測し, 過去の研究と比較して 地震の原因となった地下水の素性を明らかにしょうと試 みた。 その結果, 以下のことを明らかにすることができ た.

（1） 1966 年 9 月頃，松代地域の湧水はその湧出量も 溶存成分濃度 (主要成分 $\mathrm{Na}^{+}, \mathrm{Ca}^{2+}, \mathrm{Cl}^{-}$, 気泡状 $\mathrm{CO}_{2}$ ) も増加した。これは，長期にわたって地下に存在し， $\mathrm{Na}^{+}, \mathrm{Cl}^{-}, \mathrm{CO}_{2}$ を主成分とする深部源水が，微小クラッ ク中を地震を引き起こしつつ上昇し, かつ岩石と反応し $\mathrm{Na}^{+}$と $\mathrm{Ca}^{2+}$ とが交換しつつ地表に達したためであると 考えると理解できる，湧出量はその後低下したが溶存成 分濃度は低下せず，現在に至るまで大きな変動はない。

（2）松代の地表にみられる現在の涌水は, 各々溶存イ
オン濃度が異なる。しかし，溶存イオン組成比には一定 の関係があり，深部源水と浅層の低濃度循環水との混合 度合が異なるためであると考えると矛盾なく説明でき る. その仮定を用いて，湧水の主要イオンである $\mathrm{Na}^{+}$, $\mathrm{Cl}^{-}$の深部源水として存在するときの濃度を推定するこ とができた. それはそれぞれおよそ $310 \mathrm{meq} / l, 330$ $\mathrm{meq} / l$ である. さらに $\mathrm{Na}^{+}, \mathrm{Cl}^{-}$, 以外のイオンについ ても深層源水の濃度を推定した。これによって地震を引 き起こした深部源水の素性の一端を明らかにしたことに なる.

（3） $\mathrm{Ca}^{2+}$ の濃度は, 地表の湧水では高いが，水源の 深い水では必ずしも高くない. $\mathrm{Ca}^{2+}$ は深部源水ではも ともと少なく，それが上昇する過程において，岩石構成 鉱物中の $\mathrm{Na}^{+}$とのイオン交換によりあたらされた可能 性がある.

(4) 1966 年〜1968 年頃までは, いくつかの湧水で $\mathrm{Ca}^{2+}$ 濃度の経時変化と他のイオン $\left(\mathrm{Na}^{+}, \mathrm{Cl}^{-}\right.$など）の 経時変化には明瞭な相関がある。しかしながら現在の涌 水の短期変化においてはこの間に相関はみられない。こ れは現在の $\mathrm{Ca}^{2+}$ の濃度変化が $\mathrm{CO}_{2}$ を含んだ地下水の 上昇途中に岩石と反応した結果 $\mathrm{Ca}^{2+}$ と $\mathrm{HCO}_{3}^{-}$が生じ たものであるとすると説明できる.

\section{謝 辞}

防災科学技術研究所の吉田則夫氏には, 採水, 分析か らデー夕解釈に至るまで多くの有益な意見をいただい た. 同研究所の鈴木芳宏氏には，ボーリング資料と当時 の採水についての話を聞かせていただいた，旅館一陽館 の春日功東京水産大学名誉教授には, 測定の便宜を図っ ていただき，また過去の温泉分析書をはじめ数々の貴重 な文献を見せていただき，群発地震当時の様子について 話を聞かせていただいた。 イオンクロマトグラフなどの 分析に関しては, 信州大学理学部の福島和夫氏, ミヤマ (株)の桜井哲郎氏にご指導いただき，データの解釈など に多くのご助言をいただいた．地質調査所の小泉尚嗣氏 と東京大学地殼化学実験施設の伊藤貴盛氏には査読にお いて貴重なコメントをいただき，本論文の内容を改善す るために大変役立った。 ここに深く感謝します.

\section{文献}

青山 運, 1980-1981, 加賀井温泉の由来 (1) (12), 松代 公民館報, 270-281.

防災科学技術センター, 1970, 松代地震深層試錐による 調査及び加圧実験工事完了報告書（利根工事株式会 社), 75 .

地質調查所, $1979 a$, 松代温泉涌水の分析結果, 防災科学 技術研究資料, 41,37 . 
地質調査所, $1979 b$, 温泉水の組成，防災科学技術研究資 料, 41, 169 .

Hagiwara, T. and T. Iwata, 1968, Summary of the seismographic observation of Matsushiro swarm earthquakes, Bull. Earthq. Res. Inst., Univ. Tokyo, 46, 485-515.

掛川一夫, 1968 , 松代・稲荷山・森・代官町の温泉の成 分調査表, 更埴埴科地方誌 (自然編分冊)， $1,326$.

春日 功, 1976 , 松代地震による加賀井温泉の変化, 地 学雑誌, 76, 76-86.

Kitano, Y., R. Yoshioka, F. OKuda and K. Kazuo, 1967 , Geochemical study of ground waters in the Matsushiro area. Part 1: Chemical composition of ground waters, Bull. Disas. Prev. Res. Inst., 17, 4771

松葉谷治・酒井 均・日下部 実・佐々木 昭, 1980 , 長野県の温泉についての同位体化学的調查報告, 岡山 大学温泉研究所報告, 50, 17-24.

Morimoto, R., K. NaKamura, Y. Tsuneishi, J. Ossaka and N. TsunodA, 1967, Landslide in the Epicentral Area of the Matsushiro Earthquake Swarm Their Relation to the Earthquake Fault. Bull. Earthq. Res. Inst., 45, 241-263.

NAKAmURA, K. and Y. TUNEISHI, 1967, Ground cracks at Matsushiro probably of underlying strike-slip fault origin, I-Preliminary Report Bull. Earthq. Res. Inst., 44, 1371-1384.

中村一明, 1971, 松代地震から学んだこと一手に入れた 地震制御へのデータ一，科学朝日，10,127-133.

長野県松代保健所, $1967 \mathrm{a}$, 牧内地すべり地区湧水水質 検査結果, 松代群発地震と水質変化, 18 (防災科学技 術資料, 41 (1979), p. 68 による).

長野県松代保健所, $1967 \mathrm{~b}$, 東条地区温泉成分表, 松代群 発地震と水質変化, 19 (防災科学技術資料, 41 (1979), p. 69 による).

長野県松代保健所, $1967 \mathrm{c}$, 温泉成分経時変化松代 2 号 泉, 松代群発地震之水質変化, 20 (防災科学技術資料, 41 (1979), p. 70 による).

野口喜三雄, 1967, 松代地震と温泉, 化学と工業, 20 , 113-116.

野口喜三雄, 1968, 長野県の温泉の化学成分, 温泉化学, 18, 50-53.

野口喜三雄・上野精一・西井戸敏夫, 1969 , 松代群発地
震にともなう温泉水の変化に関する地球化学的研究, 温泉化学, 20, 67-93.

野口喜三雄・上野精一・相川嘉正・国友香子, 1970, 松 代群発地震にともなう温泉水の変化に関する地球化学 的研究第 2 報, 温泉化学, 21, 134-144.

ОнтAке, M., 1974, Seismic Activity Induced by Water Injection at Matsushiro, Japan, J. Phys. Earth, 22, 163-176.

大竹政和, 1976 , 松代地震加 10 年. 科学, 46, 306313.

笹井洋一，1995，松代群発地震の生成機構一自然発生的 大規模水圧破砕, 科学研究費総合研究研究成果報告書 「日本列島下の 3 次元電気伝導度構造と地款活動の研 究 (1)」, 181-195.

佐竹 洋・村田正信, 1998, 地下水加ら見る断層周辺の 水の動き, 月刊地球, 20, 160-164.

清水直哉・塚原弘昭・古舘友通・吉田則夫, 1998, 長野 市松代地域における炭酸ガスの湧出量と地殼変動, 地 震 $2,51,41-50$.

高橋 博, 1970 , 松代ボーリングその後と水の圧入実 験, 防災科学技術, 13, 10-13.

塚原弘昭 - 奥澤 保 - 新井崇史, 1999, 断層内流体相の 解明一松代群発地震域の湧出流体を例にして一，月刊 地球, 21, 54-58.

鶴見 実, 1979, 松代湧水の化学的特徵, 地球化学, 13, 18-23.

梅村 弘・原田康信, $1968 \mathrm{a}$, 水質調査成績 (1) 涌水, 松 代地震に伴う湧水及び水稲の塩害に関する調査と対策 試験成績書, 4 (防災科学技術資料, 41 (1979), p. 121 による).

梅村 弘・原田康信, $1968 \mathrm{~b}$, 水質調查成績 (3) 湧水・加 んがい水の時期的変化, 松代地震に伴う湧水及び水稲 の塩害に関する調査と対策試験成績書, 6-8（防災科 学技術資料, 41 (1979), pp. 123-125 による).

Wakita, H., N. FujiI, S. Matsuo, K. Notsu and N. TАКАОКA, 1978, "Helium Spots": Caused by a Diapinic Magma from the Upper Mantle, Science, 200, 430-432.

Yoshioka, R., S. OKuda and Y. Kitano, 1970, Calcium chlorade type water discharged from the Matsushiro area in connection with swarm earthquakes, Geochem. J., 4, 61-74. 